\title{
The Impact of a Proposed Interactive E-Book on Developing English language Skills of Kindergarten Children
}

\author{
Dr. Rehab Hamadtoh Abul-Ghait Gohar \\ Lecturer of Curriculum \& Instruction: TEFL \\ Faculty of Education -Mansoura University \\ gohar_rehab@yahoo.com
}

\section{Abstract:}

This study aimed at investigating the impact of designing and using an interactive electronic book (e-book) on developing the English as a foreign language (EFL) skills necessary for kindergarten children at the Egyptian language schools. $\mathrm{Kg}$ children are required to master some early language skills (namely, word meaning, listening, print awareness and phonological awareness) which were targeted in the current study. Multiple multimedia features were employed in the proposed interactive e-book such as animations, videos, interactive games, interactive worksheets, audio files and songs. Children also were able to video call their teacher through using FaceTime App. Participants were (30) Kg 2 children (aged 5-6 year) at AlWady language school. The quasi-experimental design was adopted in which the participants were equally assigned into two groups: a control group and an experimental group. Children in the experimental group were selected based on a written consent from their parents to participate in the treatment. Instruments used in the study were a checklist for identifying the target EFL skills, a standards checklist for the instructional design of the e-book and an English language test with an analytic rubric for scoring the oral and written parts of the test. Results proved that the experimental group children outperformed their control counterparts especially in the skills of listening, print and phonological awareness. However, no significant difference was found between children of the experimental and control groups in word meaning. The findings indicated that if e-books will be generalized in schools 
and for maximizing their benefit, they cannot be used totally online with teacher absence, they should be employed in a blended format with the teacher's physical presence as no electronic means can replace the effect s/he leaves through his/her direct verbal and non-verbal communication with the children.

\section{Key words:}

Interactive electronic book, English language skills and kindergarten children.

\section{Introduction:}

Increased globalization has promoted the English language as one of the most widely used around the globe; thus, communicating in English as a second/foreign language is becoming an important aspect of academic and social success. Learning English is accordingly an essential issue for parents to consider when planning their children's future. In Egypt, English is not an official language and all people use Arabic for daily communication. English language has been introduced by the Egyptian Ministry of Education as a compulsory subject in the kindergarten school curriculum for a very long time due to the multiple advantages of learning a language at a very early age.

Dunn (2013) stated that young children are natural language acquirers; they are self-motivated to pick language without conscious learning. They are able to imitate word pronunciation and work out the rules for themselves. There are many advantages of beginning early. For example, young children use their innate language-learning strategies to pick up English. They also have time to learn through play-like activities. They acquire language by participating in an activity shared with an adult. They firstly make sense of the activity and then form meaning from the adult's shared language. In addition, they have more time to fit English into the daily school program as 
they have little or no homework and are less stressed by having to fulfill difficult tasks. Furthermore, young children are more likely to have better pronunciation and feeling for the language.

Similar to being able to learn a new language at an early age, young children can easily use tablets, computers or even ipads to have fun and learn at the same time if they have access to technology as a learning tool. The development of information and communication technologies (ICT) has initiated a rapid transformation in education all over the world. In all levels, starting from kindergarten till after university level, learners can use the various interactive e-learning tools to develop their skills, knowledge and perception of the world. It is time for traditional education to be replaced with up-to-date learning systems that can be tailored in response to learners' future needs.

The present study tried to make use of the various attractive and interactive features offered through an interactive e-book to develop kindergarten children's English language skills.

\section{Review of related literature:}

Despite some of the challenges in introducing English for kindergarteners as a foreign language (FL) over the last few decades, and the relative limited research in this area, a number of researches have demonstrated the potential in very young children learning a FL. Although limited in their extent, researches do suggest that while very young children are capable of learning a FL, this does not necessarily imply the "earlier the better". Successful language learning depends on the environment provided, teaching quality, some motivational factors, etc. (Murphy, 2014). Consistent with this, after reviewing literature related to teaching EFL, Zhou and $\mathrm{Ng}$ (2016) summarized that the problems of implementing EFL in the pre-school stage include: inadequate time dedicated for language learning, inappropriate 
teacher training, insufficient authentic `materials, inappropriate teaching methods, discontinuity of provision for language teaching, and inappropriate media used.

Al-Darwish (2013) examined the English curriculum of the Kuwaiti kindergarten stage and the perceptions of the teachers and parents in an attempt to identify areas that need to be improved to enhance English learning of those children. In addition, the delivery of information and sequence of interaction in relation to the learning process of English as a foreign language in kindergarten stage in Kuwait were assessed. Results of the study recommended that the kindergarten children need more innovation and opportunities for practicing real communication skills in the English class.

Mohammed (2016) assessed the development of pre-school children's language skills highlighting the imbalance between their L1 (first language) and L2 (second or foreign language). It was proved that there is a failure to fulfill a reasonable match between the two languages. It was indicated that children seemed to have a good knowledge of vocabulary; however, they took longer to recall the words. In addition, concerning children's phonological awareness, more attention, in most lessons, was given to improving children's letter recognition and writing. Very little focus was directed to relating symbols with sounds. Thus, children were observed to have difficulty sounding out words and making connections between letter combinations and sounds.

Young children develop their native language skills whether reading, writing, listening, or speaking at a very early age; however, when learning a foreign language, the oral skills must be the foundation of their kindergarten learning program. Besides, children whose first language is not English would face a lot of difficulties to comprehend and produce the language if 
rich linguistic environments are not saved to learn English. Such environments must provide various opportunities for kindergarten children to live and communicate through real things and events. Children need real or virtual contexts inside and outside the classroom to practice English where errors are accepted and recognized as part of the learning process. A revolutionary action should be taken against weak traditional textbooks, traditional teaching methods as well as traditional kindergarten teachers if we want to build harmonious characters endowed with a high self- concept and produce students with advanced English levels who are able to deal creatively in the current age of communication technology.

The rapid expansion of ICT and e-learning made it possible to provide students of different ages with a large range of learning experiences because of its advantages over traditional printed books. Research suggests that ICT can provide a context for collaboration, co-operation, interaction and positive learning experiences between children, or between children and adults. To reach this, practitioners must be aware of the types of learning interactions they would like to occur in the ICT environment (between adults and children, or among children), and adopt the appropriate pedagogical strategies to enhance such interactions. Case studies show how ICT can be employed to support aspects of learning, including language development and the development of mathematical thinking. In addition, ICT offers unique opportunities for scaffolding and for children to weave together words, pictures, and sounds, thereby providing a range of ways for children to communicate their ideas, thoughts, and feelings. Good software/application can allow children to engage in self-directed exploration and can be tailored to children's individual needs (Bolstad, 2004).

Similarly, Sunhaloo, Narsoo and Gopaul (2009) emphasized that elearning increases the speed and degree of disseminating knowledge. It also 
facilitates the acquisition of knowledge and skills and provides flexible learning opportunities. An interactive online e-learning tool was implemented for kids in Mauritius to promote e-learning in the country. The tool supported the development of a data exchange methodology; the kids became independent and were allowed to learn at their own pace; and they increased their knowledge in a more interactive way. Besides, the e-tool promoted learning through animation, interactive application, fun, and meaningful activities.

A study by Couse and Chen (2010) investigated preschool children's ease in acclimating to tablet technology and its effectiveness in engaging them to draw. Participants of 41 three- to six-year old children were videotaped while they used the tablets. The study found significant differences in level of tablet use between sessions, and increased engagement with age. Teachers reported high child interest and ease in drawings through tablets in spite of the existence of some technical problems.

Khoo, Merry, \& Nguyen, with Bennett \& MacMillan (2015) assessed the use of ipads or tablets in the education of young children. According to the findings, using the iPad or the tablet can support children's developing literacy, communicative and participatory learning skills and understandings. This is due to its multiple key features including its portability/mobility, internet connectivity, touchscreen, and educational apps allowing for new and different ways of teacher-child/children interaction and the exploration of children's learning interests. The iPads served as a relational, a communicative, a documentation, an informational, and finally an observational tool that could support child-led learning.

Coping with such new technology, digital texts and e-books are replacing traditional printed books. E-books provide a context for learners where they 
can actively engage in rich and diverse authentic experiences that motivate and inspire them. The different tasks that children accomplish in such a rich electronic environment enable them to reach their optimal learning level due to the attractive, interactive, communicative and up-to-date instructional style.

Zucker, Moody and McKenna (2009) described e-book as a digital form of a book including similar features to regular printed books (e.g. central themes, pages that turn, etc.); however, they are different as they often contain some electronic enhancements (e.g. animations, electronic games, sounds, etc.).

E-books often include rich multimedia features that cannot be found in textbooks. Such features might contain recordings of the text, read-aloud, lively animations, music, videos and other different effects. Moody (2010) indicated that the use of high quality interactive e-story books may support language development through the use of scaffolding; thus, supporting vocabulary development, engagement and comprehension of the story. Lower quality e-books may offer distracting digital features including animations and sounds unrelated to the story.

Grimshaw (2007) stated that features of electronic books (e.g. audio narration, animations) can have a positive impact on children's reading comprehension skills because such features help children decode new words which enhance their understanding of the text. Moreover, voice narration supports children in pronouncing words. It was also added that there is a psychological element to studying e-books since many children are shy and reluctant to ask a teacher for help in a classroom. Thus, children are motivated to study and read without fear of failure because e-books actively engage their minds. 
E-books can have many attractive features that allow children to interact with the text. For example, readers may touch the pages to make sound, make objects move, or even access multimedia content such as videos, games and puzzles. Such interactive features often bring the book to life. E-books might have what is called "seductive interaction effect" which might bring three potential outcomes: distracting, supporting or extending children's comprehension (Smith and Schugar, 2013).

Smith and Schugar (2013) provided also four criteria for designing interactive e-books:

1. Illustrations and animations provide vocabulary and interface support.

2. Interactions supporting and extending students' comprehension are significant.

3. The length of time that the interactions pull children away from the text should be considered.

4. The frequency and placement of the e-book's interactive features should also be considered.

Phadung, Suksakulchai and Kaewprapan (2012) presented four main categories for designing interactive storybooks:

a) Multimedia design: how the multimedia features (e.g. pictures, animations, text, narrations) are presented.

b) Interface design: strategies used to encourage interaction with the book.

c) Learning design: strategies used to encourage children's language development.

d) Cultural design: strategies for incorporating cultural themes for promoting children's thinking skills.

Some studies were conducted to assess the use of e-books to develop children's language learning. For example, Maynard (2005) compared how 
much children learn from e-books in comparison to printed books. Half of the children used an electronic CD-ROM filled with animations, sound effects, music and videos; while the other half used a printed book. Findings proved that those who used the e-textbook did better on the comprehension tests than those who used the printed textbook.

Korat and Shamir (2007) indicated that it is the strategic design of the ebook that affects the comprehension and development of language skills. When they created and applied an attractive e-book while also supporting comprehension, it was found that children had levels similar to children reading through print versions.

In addition, Korat (2008) assessed the improvement of children's language skills after using an e-book over a period of time. The results proved that children showed improvement in word meaning, recognition and phonological awareness after being exposed to the developed e-book.

Consistently, Smeets and Bus (2014) examined the impact of the features associated with electronic picture storybook on children's word learning and story comprehension. Participants of this study were kindergarten children assigned to four groups: static e-books, animated e-books, interactive animated e-books and a control group. Results revealed that strong treatment effects were found on the target vocabulary. Children gained most in vocabulary after reading interactive animated e-books, followed by (noninteractive) animated e-books, and then static e-books. Results recommended that e-books are valuable additions in support of the classroom curriculum with interactive animated e-books being the best alternative.

Moreover, Takacs, Swart, and Bus (2015) examined the impact of technology-enhanced stories for children's literacy development when compared to listening to stories in more traditional settings like storybook reading. Results proved that technology-enhanced stories and multimedia 
features such as animated pictures, music, and sound effects were found beneficial. In contrast, interactive elements like hotspots, games, and dictionaries were found to be distracting.

However, some researchers raised some concerns about the use of ebooks for kids. For example, DeJong and Bus (2003) found that e-books do not effectively enhance comprehension of story content and that children spent $43 \%$ of their e-book engagement time playing games rather than reading the text. It was concluded that attractive multimedia features distracted children's attention to the text rather than providing meaningful interactions.

In addition, Davies (2012) reviewed the previous literature that measured the effectiveness of e-book technology in promoting early literacy skills in young children compared to traditional print-based methods. Findings of this critical review neither fully support nor refuse the use of e-books to assist the development of emergent literacy/language skills. The study recommended conducting further experiments to determine if e-books are as effective as traditional print books in promoting language/literacy skills.

Supporting such concerns about the use of digital books, Wang and Yang (2014) investigated the effect of an interactive e-book design on the learning of Chinese characters by fourth graders (10-year-old children). Participants were randomly assigned into two groups, with one group reading an e-book with a low level of interactivity (pace-control only) and the other reading an e-book with a high level of interactivity (sequence- and media-control). The results showed a reverse interactivity effect, that is, the group reading the ebook with the low level of interactivity (pace-control only) performed significantly better in writing, attention, and satisfaction. This might be due 
to children's limited cognitive and processing ability for learning with hypermedia.

Based on what has been mentioned above, it is obvious that many studies recommended using e-books over traditional printed books for developing children's different skills due to the advantages of using sounds, videos, animations and many other online applications. However, Bayhan, Olgun, \& Yelland (2002) and House (2012) had some concerns regarding the potential harmful social and learning effects in exposing young children to "screen media" based technologies at a tender age; with others emphasizing that computers are "neither appropriate or important" (Downes, Arthur, \& Beecher, 2001: 139) in early childhood settings. Jenkins, et al. (2006) emphasized that such criticism at screen media-based technology is directed without considering the supportive effect that technology might produce on children's interactions, collaboration and learning especially in the presence of caring adults, teachers and parents who can provide scaffolds for their learning. That is why interactive electronic books provided through tablets or ipads can certainly supplement children but are still no true replacement for an adult reading to them a storybook. Yet, the current study attempted to assess the effectiveness of designing and using an interactive e-book in developing kindergarten children's English language skills.

\section{Statement of the problem:}

Based on the previous background which fosters the impact and significance of interactive e-books over printed books, the current research aimed at investigating the impact of a proposed interactive e-book on developing the English language skills necessary for Kindergarten children.

\section{Questions of the Study:}

The present study answered the following questions: 
1. What are the English language skills necessary for kindergarten children to master?

2. What are the standards of instructional design required for designing the proposed interactive e-book?

3. What is the instructional design of the proposed interactive e-book for developing the English language skills of kindergarten children?

4. What is the impact of the proposed interactive e-book for developing the English language skills of kindergarten children?

\section{Purpose of the Study:}

The present study aimed at assessing the impact of a proposed interactive e-book on developing English language skills of kindergarten children.

\section{Delimitations:}

The study was delimited to the following:

1. A sample of children at KG2 at Al-Wady language school.

2. Some English language skills assigned based on reviewing literature and the teacher's guide of Family and Friends (2) (adopted from Oxford) for $\mathrm{KG} 2$.

3. Unit (8) entitled "Mealtime" from the series of First Friends (level 2) for KG2.

4. A proposed interactive e-book employing multiple multimedia features and electronic techniques such as FaceTime app, videos, animations, music, sound effects, audio authentic materials and interactive games. 


\section{Operational definition of terms:}

\section{Interactive e-book:}

A digital version of the printed book employing multiple interactive electronic features such as animations, video clips, interactive games, worksheets, authentic audio files, songs and FaceTime App.

\section{English language skills:}

The skills which are necessary for kindergarten children to master at this young age. Those English language skills are identifying word meaning, print awareness, listening and phonological awareness

\section{Instruments:}

For the purpose of the study, the following instruments were designed and implemented by the researchers:

1. A checklist for determining the English language skills required for KG2 children.

2. A standards checklist for designing the proposed interactive e-book for KG2.

3. A test for assessing the target English language skills for KG2 children. An analytic rubric for scoring the oral part of the English language test in addition to children's writing was also designed.

\section{Hypotheses:}

The present study tested the following hypotheses:

1. There is a statistically significant difference at 0.05 level between the mean ranks of the control group and the experimental group on the post application of the English language test in favor of the experimental group. 
2. There is a statistically significant difference at 0.05 level between the mean ranks of the experimental group pre-post application of the English language test in favor of the post application.

\section{Participants:}

The experiment involved the participation of 30 children (aged 5-6 year) at KG2, at Al-Wady language school. They were assigned to two groups: one control and one experimental; and each group consisted of 15 children. Children of the experimental group were selected according to their computer skills. An interview with the school teacher of computer indicated that those children are able to deal with the computer and they have personal tablets. Written permission (Appendix 1) was taken from the parents of the target participants to study the selected unit electronically through the tablet or in the computer lab. Parents were also enthusiastic and approved on helping their children to deal with the assigned digital home fun activities.

\section{Design:}

The study adopted the quasi-experimental design using two groups: an experimental and a control group. The experimental group studied through the proposed interactive e-book, while the control group received the regular English class. Both groups received the pre- and post-application of the English language test.

\section{Procedures:}

\section{First, designing the instruments of the study:}

A. The checklist of the English language skills.

A checklist was prepared for determining the English language skills necessary for KG2 children to adopt. Those target skills were reached based 
on reviewing literature related to kindergarten education and the EFL skills required for children to master at this very young level. Besides, the teacher's guide of First Friends (2) (adopted from Oxford) for KG2 was reviewed to identify the basic EFL skills addressed throughout its content. The initial form of that checklist was presented to some EFL specialists to check its validity. After doing their necessary recommendations, the final list of the EFL skills necessary for KG2 children was presented as follows:

1. Identifying word meaning

2. Print awareness including:

- Writing correct words and numbers

- Writing proper letter shapes by following the appropriate left to right sequence of English.

- Using some fine motor skills (directionality and using straight lines).

3. Listening.

4. Phonological awareness

- Pronouncing sounds, separate words and simple sentences.

- Distinguishing between rhyming words.

- Distinguishing separate letters.

B. The standards checklist for designing the proposed interactive e-book.

In order to meet the different needs of the children, the interactive e-book should reflect good internal designs that enhance the development of early language skills and facilitate active learning. Thus, the main standards of designing the frame work of the proposed interactive e-book were adapted from Phadung, Suksakulchai and Kaewprapan (2012). The standards (appendix 2) were categorized in the following four main domains:

1. Multimedia design: includes the guidelines of presenting multimedia employed in the e-book, for example, videos, pictures, animations, narrations, etc. 
2. Interface design: addresses the guidelines for designing the interaction between the courseware and the children.

3. Learning design: includes the guidelines as the strategies to support children's language development.

4. Cultural design: adopts the guidelines for incorporating cultural themes to promote early language learning.

C.The EFL test and its rubric for measuring children's English language level:

An English language test was designed for: identifying the homogeneity level of the control and experimental groups and determining the participants' pre-and post-levels in the target English language skills. The target English language skills were measured as follows:

\section{Word meaning}

Children were asked for the meanings of eight main new words selected from the target unit. This was done through: a matching question in which they matched the word with its proper picture and a second question in which four pictures were presented to the children and three written forms were suggested for each picture, the children were asked to circle the proper written form.

\section{Print awareness}

This skill was measured through assessing three sub-components. First, children's skill of writing correct words and numbers was measured by presenting four pictures in which they were asked to write the words and count and write the appropriate number. Second, children's ability to write proper letter shapes following the appropriate left to write sequence of English was assessed by giving children four pictures and asking them to write the missing letter; children were observed to determine if they follow 
the proper writing sequence or not. Third, children's writing in the overall test was also observed to measure their use of some fine motor skills like directionality and using straight lines.

\section{Listening}

To measure children's listening skill, they were asked to listen to some words orally presented to them and select the proper picture that represented the word. In addition to assessing their sound discrimination ability, they were asked to point to the proper sound after listening to two different sounds.

\section{Phonological awareness}

Children's phonological awareness was measured by three different question, all focused on pronunciation and reading. The first question asked children to pronounce separate words and simple sentences elicited for the target unit. Children were also asked to read and distinguish between rhyming words in the second question. Moreover, in the third question, four-pairs of separate letters were presented to children for discriminating them.

A rubric was designed for scoring children's answers in the writing and pronunciation questions of the EFL test. (The test and the rubric are presented in appendix 3).

Reliability of the English language test was estimated through getting the coefficient of internal consistency ( $\alpha$ Cronbach). 15 children other than the main participants of the experimental and control groups were selected to be the sample of the pilot study. The value of ( $\alpha$ Cronbach) was 0.76 which indicated the reliability of the test.

\section{Second, designing the interactive e-book:}

Interactive e-books can provide rich and flexible environments for meeting children's' different language skills and needs. For designing the proposed interactive e-book, the main phases of Khamis (2007) and Al-Gazar (2014) were employed as follows: 
1. Study and analysis: This phase included studying and analyzing the characteristics of the target participants ( $\mathrm{Kg} 2$ children). Based on the literature and studies previously mentioned, it was indicated that children at this very young age face a lot of difficulties to comprehend and produce English if attractive and authentic linguistic experiences are not saved for them. Furthermore, the significance of digital e-books was stressed over traditional books as they provide real language context for the children in which errors are accepted and constructive immediate feedback is provided. 2. Design: This phase included the procedures followed in the design of the proposed interactive e-book. These procedures were determining the target objectives of the e-book, preparing the content, preparing the learning experiences, and designing the scenario of the e-book. These procedures are explained as follows:

2-1. Target objective of the interactive e-book is developing the target English language skills necessary for $\mathrm{Kg} 2$ children as they are previously determined.

2-2. Content: The content of the proposed interactive e-book is mainly activity-based. Unit (8) entitled "Mealtime" from the series of First Friends (level 2) for KG2 was selected and designed to fit the interactive e-content. That unit included (6) lessons addressed for achieving the target EFL skills. Different interactive features were inserted in each lesson to enable the children to interact with the content in a way different from their interaction with traditional printed books.

2-3. The learning experiences and materials: The e-book provides the children with multiple experiences and interactive materials. It enables the children to touch the pages to make sound or even access multimedia content such as animations, videos, interactive games, interactive worksheets, audio 
files and songs. For example, it allows the children to click on the word to have it pronounced to them and a clearer picture appears for enhancing their understanding of the word. In addition, children are engaged in some interactive games for promoting their phonological awareness, such as segmenting words into syllables, distinguishing sound and rhyming words. Some interactive worksheets are also designed for training children on visual discrimination (including letter discrimination). Immediate feedback is given to children on their spoken or written language.

2-4. Designing how the children proceed in the proposed interactive e-book: Each child uses his/her personal tablet and logins to the e-book using his/her password so that $\mathrm{s} / \mathrm{he}$ can access the target interactive e-unit. The children study through various interactive materials and perform different types of interactive activities under teacher's guidance in the classroom. Moreover, they are provided with some extensive activities to be done via the e-book at home under the guidance of their parents. A teacher's guide (appendix 4) and some guiding instructions for parents (appendix 5) are prepared for facilitating children's flow in the interactive e-book.

2-5. Designing the scenario of the interactive e-book.

The scenario is the designed plan for producing the online environment which includes its details and preparation steps, the online tools, multimedia elements, content, and instructions. It provides a detailed description of how the written texts are transformed into visuals and videos to form the pages of the interactive e-book. The scenario of the cover page of the e-book and a sample lesson is presented in the following tables. The interactive e-book was then technically designed and produced using articulate storyline 360 program. 
Table 1: Scenario of the book cover

\begin{tabular}{|c|c|c|c|c|c|c|c|c|}
\hline \multirow{2}{*}{$\begin{array}{l}\text { Title of the } \\
\text { screen }\end{array}$} & \multirow{2}{*}{$\begin{array}{l}\text { Contents of the } \\
\text { screen }\end{array}$} & \multicolumn{3}{|c|}{ Multimedia elements } & \multirow{2}{*}{\multicolumn{3}{|c|}{ Screen design }} & \multirow[t]{2}{*}{ Hyperlinks and navigation } \\
\hline & & Written text & $\begin{array}{l}\text { Graphics and } \\
\text { pictures }\end{array}$ & Video & & & & \\
\hline $\begin{array}{l}\text { The cover } \\
\text { page of the } \\
\text { interactive } \\
\text { e-book }\end{array}$ & $\begin{array}{l}\text { The cover page } \\
\text { contains the image } \\
\text { of the book cover } \\
\text { whose title is } \\
\text { Family and Friends } \\
(2) \text { logo and a } \\
\text { subtitle which is } \\
\text { "English for Fun", } \\
\text { buttons for video } \\
\text { clips, songs, } \\
\text { activity book and } \\
\text { play time. In } \\
\text { addition, it includes } \\
\text { teacher's corner, } \\
\text { parent's corner, and } \\
\text { FaceTime. }\end{array}$ & $\begin{array}{l}\checkmark \text { Title of the book } \\
\text { which is "Family } \\
\text { and Friends (2)" } \\
\checkmark \text { English for Fun. } \\
\checkmark \text { Welcome message. }\end{array}$ & $\begin{array}{l}\checkmark \text { Logo of } \\
\text { interactive e-book. } \\
\checkmark \text { The image of the } \\
\text { book cover. }\end{array}$ & & 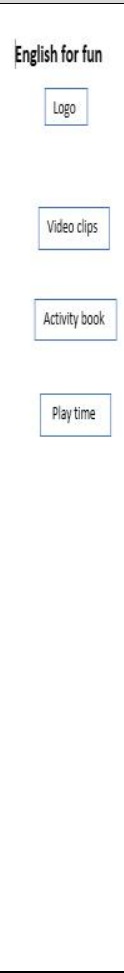 & 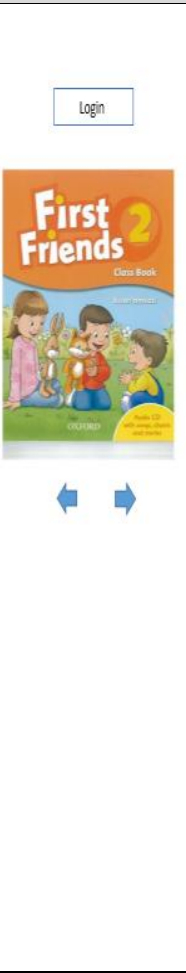 & 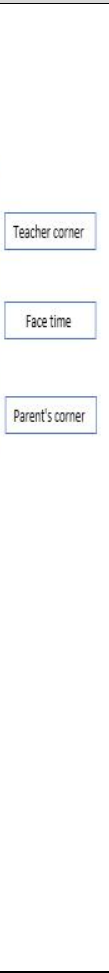 & $\begin{array}{l}\text { The content of the buttons does not appear } \\
\text { unless the child logins first. When } \\
\text { touching login, the child can sign in using } \\
\text { his/her password. When clicking the video } \\
\text { clips, songs, activity book, and play time } \\
\text { buttons, the child accesses materials } \\
\text { related to each lesson. However, such } \\
\text { buttons are deactivated in the book cover } \\
\text { till moving to the lessons of the target unit. } \\
\text { FaceTime App is also employed so that } \\
\text { the child can conduct a video call with the } \\
\text { teacher in a pre-determined time. In } \\
\text { addition, the teacher logins with his/her } \\
\text { password to access the e-book. When s/he } \\
\text { touches the teacher's corner button, a pop- } \\
\text { down menu appears including teacher's } \\
\text { guide and instructions for using the book. } \\
\text { Furthermore, the parent has a role as s/he } \\
\text { can access some instructions and } \\
\text { guidelines for helping and monitoring } \\
\text { his/her child's use the e-book at home } \\
\text { through clicking parent's corner. }\end{array}$ \\
\hline
\end{tabular}


Table 2: Scenario of the $1^{\text {st }}$ lesson of unit (8)

\begin{tabular}{|c|c|c|c|c|c|c|}
\hline \multirow{2}{*}{$\begin{array}{l}\text { Title of the } \\
\text { screen }\end{array}$} & \multirow{2}{*}{$\begin{array}{l}\text { Contents of the } \\
\text { screen }\end{array}$} & \multicolumn{3}{|c|}{ Multimedia elements } & \multirow[t]{2}{*}{ Screen design } & \multirow[t]{2}{*}{ Hyperlinks and navigation } \\
\hline & & Written text & $\begin{array}{c}\text { Graphics and } \\
\text { pictures }\end{array}$ & Video & & \\
\hline $\begin{array}{l}\text { The cover } \\
\text { page of the } \\
\text { interactive } \\
\text { e-book }\end{array}$ & $\begin{array}{l}\text { The image of the } 1^{\text {st }} \\
\text { lesson of unit (8), logo } \\
\text { reflecting the "English } \\
\text { for Fun" principle, } \\
\text { buttons for video clips, } \\
\text { songs, activity book } \\
\text { play time, teacher's } \\
\text { corner, parent's corner, } \\
\text { and FaceTime. }\end{array}$ & $\begin{array}{l}\checkmark \text { Title of the unit } \\
\text { which is } \\
\text { "Mealtime" } \\
\checkmark \text { The EFL } \\
\text { vocabulary of the } \\
\text { lesson } \\
\checkmark \text { Listen and say } \\
\checkmark \text { Listen and find }\end{array}$ & $\begin{array}{l}\checkmark \text { Logo of } \\
\text { interactive e- } \\
\text { book. } \\
\checkmark \text { The image of the } \\
\text { first lesson of the } \\
\text { unit. } \\
\checkmark \text { A clearer image } \\
\text { is presented } \\
\text { when touching } \\
\text { each English } \\
\text { word. }\end{array}$ & \begin{tabular}{|l} 
When \\
clicking \\
video \\
clips, a \\
video \\
related \\
to the \\
lesson \\
appears
\end{tabular} & 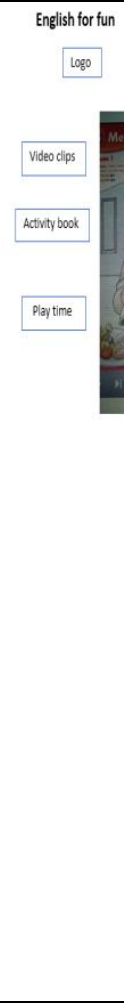 & $\begin{array}{l}\text { After logging in, the child accesses the e-book. After } \\
\text { dragging the cover page, s/he accesses the screen of } \\
\text { the first lesson. When touching each of the EFL } \\
\text { words of the lesson, the child listens to its } \\
\text { pronunciation and a clearer image of the word } \\
\text { appears to enhance word meaning. When touching } \\
\text { "Listen and say", the child listens to words' } \\
\text { pronunciation and repeats. When also touching } \\
\text { "Listen and find", s/he listens to the word and selects } \\
\text { the matching picture, and then s/he receives } \\
\text { immediate feedback in the form of clapping or music. } \\
\text { Moreover, when touching the video clips button, the } \\
\text { child accesses the clarifying video related to the } \\
\text { content of the lesson. When clicking the songs button, } \\
\text { a song is presented. When touching activity book, } \\
\text { activities of the children's activity book are } \\
\text { redesigned and presented in an interactive electronic } \\
\text { way. When touching the play time button, some } \\
\text { interactive games based on the content of each lesson } \\
\text { are presented to enhance children's comprehension } \\
\text { and acquisition of the target literacy skills in a funny } \\
\text { technique. The child can also conduct a video call } \\
\text { with the teacher through FaceTime App based on a } \\
\text { pre-determined time. In addition, there are teacher's } \\
\text { corner and parent's corner as previously explained. }\end{array}$ \\
\hline
\end{tabular}




\section{- Procedures of the experimental intervention:}

An equivalent group design with one experimental group and one control group was used in the present study. The following steps were followed:

\section{- Pre- intervention}

The children's English language level was assessed before conducting the experimental treatment at the end of the first semester of the academic year 2016/2017. Homogeneity between participants of the control and the experimental groups was established through administering the English language skills test to both groups before administering the experimental treatment. Because the children are very young, the test was administered in two sessions. Table (3) shows whether there is any significant difference between the control and experimental groups concerning the test preadministration.

Table (3)

$U$-Value for the difference between the control and experimental groups on the pre-administration of the English language skills test

\begin{tabular}{|c|c|c|c|c|c|c|}
\hline Skills & Groups & $N$ & $\begin{array}{l}\text { Mean } \\
\text { Rank }\end{array}$ & $\begin{array}{l}\text { Sum of } \\
\text { Ranks }\end{array}$ & $U$ & $\begin{array}{l}\text { Sig. (2- } \\
\text { tailed) }\end{array}$ \\
\hline \multirow{2}{*}{ Word meaning } & Control & 15 & 15.70 & 235.50 & \multirow{2}{*}{109.5} & \multirow{10}{*}{$\begin{array}{l}\text { Not } \\
\text { Sig. }\end{array}$} \\
\hline & Exp. & 15 & 15.30 & 229.50 & & \\
\hline \multirow{2}{*}{ Print awareness } & Control & 15 & 15.50 & 232.50 & \multirow{2}{*}{112.5} & \\
\hline & Exp. & 15 & 15.50 & 232.50 & & \\
\hline \multirow{2}{*}{ Listening } & Control & 15 & 15.20 & 228.00 & \multirow{2}{*}{108} & \\
\hline & Exp. & 15 & 15.80 & 237.00 & & \\
\hline \multirow{2}{*}{$\begin{array}{c}\text { Phonological } \\
\text { awareness }\end{array}$} & Control & 15 & 15.20 & 228.00 & \multirow{2}{*}{108} & \\
\hline & Exp. & 15 & 15.80 & 237.00 & & \\
\hline \multirow{2}{*}{ Total } & Control & 15 & 14.80 & 222.00 & \multirow{2}{*}{102} & \\
\hline & Exp. & 15 & 16.20 & 243.00 & & \\
\hline
\end{tabular}

Non-parametric Mann-Whitney U-test was used for calculating the difference between the control and experimental groups on the preadministration of the English language skills test. Data shown in the 
above table indicates that $\mathrm{U}$-value is not significant in the four main skills and in the total score of the English language test; this proves that there is no significant difference between the mean ranks of the control and experimental groups on the pre-test. In other words, the homogeneity was established since the two groups are equivalent in their English language level before conducting the treatment.

\section{- The intervention:}

The proposed interactive e-book was administered to children of the experimental group. The control group studied through the regular English class. The experimental treatment was conducted in the second semester of the academic year 2016/2017.

For introducing the e-book to the children for the first time, a 45-minute session was provided to the children to train them on the basic technological skills they would need to navigate an e-book on their personal tablets. Familiarizing children with the e-books was achieved through: 1) showing how to turn on the device, login and access the apps they would need; and 2) demonstrating how to turn pages and use the interactive features. Children would also use their tablets frequently at home under parents' guidance to gain more confidence.

The experimental group children studied through the interactive e-book using their tablets in the classroom or in the computer lab and at home under their parents' guidance. They work in a personalized learning manner through the interactive activities and communicating with the teacher and their peers, they then receive appropriate immediate feedback. The children and their parents can even communicate with the teacher while being at home through FaceTime App at a predetermined time for any clarification or assistance. 


\section{- Post- intervention:}

The post-administration of the instruments (the English language test and its rubric) was conducted after the experimental treatment to examine the improvement in children's English language level for both the control and experimental groups.

\section{Results:}

\section{Testing the first hypothesis:}

Non-parametric $\mathrm{U}$ test for independent samples was used to test the first hypothesis which is" There is a statistically significant difference at 0.05 level between the mean ranks of the control group and the experimental group on the post application of the English language skills test in favor of the experimental group". The following table illustrates the results:

Table (4)

$U$-Value for the difference between the control and experimental groups on the post-administration of the English language skills test

\begin{tabular}{|c|c|c|c|c|c|c|}
\hline Skills & Groups & $N$ & $\begin{array}{l}\text { Mean } \\
\text { Rank }\end{array}$ & $\begin{array}{c}\text { Sum } \\
\text { of } \\
\text { Ranks }\end{array}$ & $\boldsymbol{U}$ & $\begin{array}{l}\text { Sig. }(2- \\
\text { tailed })\end{array}$ \\
\hline \multirow{2}{*}{ Word meaning } & Control & 15 & 14.87 & 223.00 & \multirow{2}{*}{103} & \multirow{2}{*}{ Not Sig. } \\
\hline & Exp. & 15 & 16.13 & 242.00 & & \\
\hline \multirow{2}{*}{$\begin{array}{c}\text { Print } \\
\text { awareness }\end{array}$} & Control & 15 & 11.40 & 171.00 & \multirow{2}{*}{51} & \multirow{2}{*}{$\begin{array}{l}\text { Significant } \\
\text { at } 0.05\end{array}$} \\
\hline & Exp. & 15 & 19.60 & 294.00 & & \\
\hline \multirow{2}{*}{ Listening } & Control & 15 & 10.47 & 157.00 & \multirow{2}{*}{37} & \multirow{2}{*}{$\begin{array}{l}\text { Significant } \\
\text { at } 0.05\end{array}$} \\
\hline & Exp. & 15 & 20.53 & 308.00 & & \\
\hline \multirow{2}{*}{$\begin{array}{c}\text { Phonological } \\
\text { awareness }\end{array}$} & Control & 15 & 10.40 & 156.00 & \multirow{2}{*}{36} & \multirow{2}{*}{$\begin{array}{l}\text { Significan } \\
\text { at } 0.05\end{array}$} \\
\hline & Exp. & 15 & 20.60 & 309.00 & & \\
\hline \multirow{2}{*}{ Total } & Control & 15 & 9.07 & 136.00 & \multirow{2}{*}{16} & \multirow{2}{*}{$\begin{array}{l}\text { Significant } \\
\text { at } 0.05\end{array}$} \\
\hline & Exp. & 15 & 21.93 & 329.00 & & \\
\hline
\end{tabular}

Table (4) shows that the mean ranks of the experimental group in three language skills (print awareness, listening and phonological awareness) are higher than those of the control group. The table illustrates also that the 
estimated U-value is significant at .05 level. However, U-value is not significant when comparing the mean ranks of both the experimental (16.13) and control group (14.87) concerning the skill of identifying word meaning; this implies that there is no difference between the two groups in that skill. This can be attributed to the techniques of showing word meaning used by teacher of the control group according to the regular teaching method. Examples of those techniques include using pictures, flashcards, realia, miming, etc. Such techniques are similar to the ones adopted in the interactive e-book but presented in a digital form.

Regarding the total difference between the two groups in all EFL skills, data shown in the previous table concludes that the total mean rank of the experimental group (21.93) is higher than the control group (9.07). The estimated U-value $(=16)$ also supports the statistically significant difference between the experimental and control groups in their overall English language performance. Moreover, the following graph reflects the previously discussed differences between the control and experimental groups which led to accepting and verifying the first hypothesis.

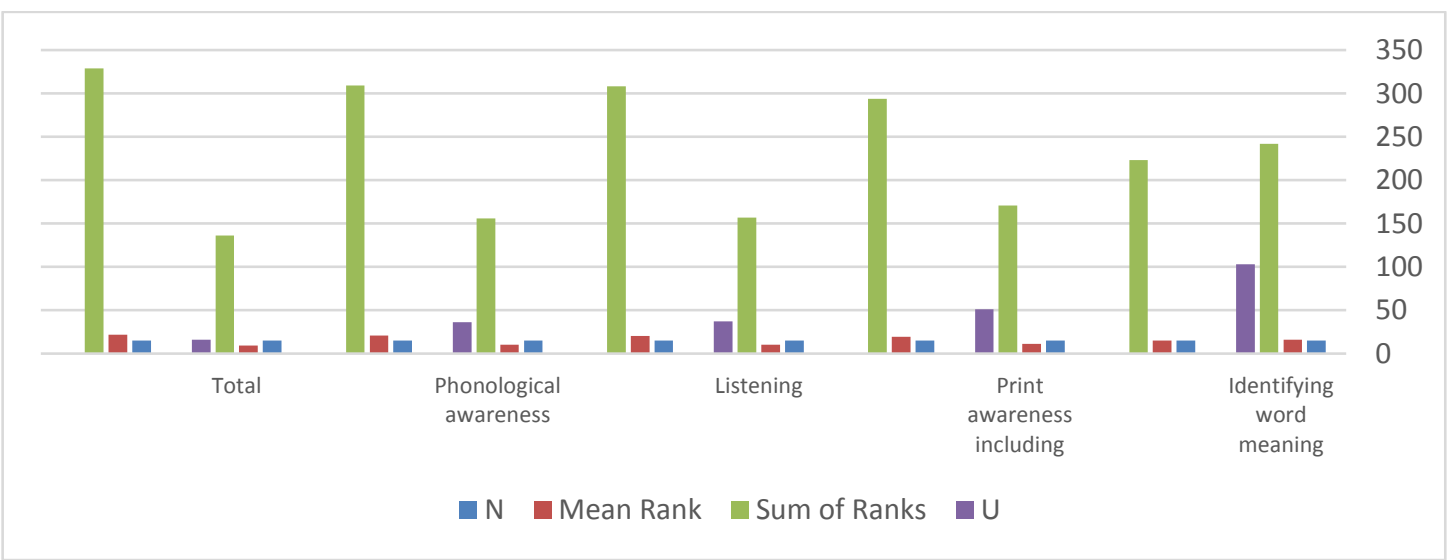

Figure (1). The differences between the experimental and control groups in the post-administration of the English language skills test

\section{Testing the second hypothesis:}

The Wilcoxon signed-rank test for dependent samples was used to test the second hypothesis which addressed the significant difference 
between the mean ranks of the experimental group's pre \& post application of the English language skills test. Results are shown in the following table.

Table (5)

Z-Value for the difference between the experimental group's pre-post-administration of the English language skills test

\begin{tabular}{|c|c|c|c|c|c|c|}
\hline Skills & Ranks & $N$ & $\begin{array}{l}\text { Mean } \\
\text { Rank }\end{array}$ & $\begin{array}{c}\text { Sum of } \\
\text { Ranks }\end{array}$ & $Z$ & $\begin{array}{c}\text { Sig. } \\
(2- \\
\text { tailed })\end{array}$ \\
\hline \multirow{4}{*}{$\begin{array}{c}\text { Identifying word } \\
\text { meaning }\end{array}$} & Negative Ranks & 0 & .00 & .00 & \multirow{4}{*}{3.43} & \multirow{20}{*}{ n } \\
\hline & Positive Ranks & 15 & 8.00 & 120.00 & & \\
\hline & Ties & 0 & & & & \\
\hline & Total & 15 & & & & \\
\hline \multirow{4}{*}{ Print awareness } & Negative Ranks & 0 & .00 & .00 & \multirow{4}{*}{3.45} & \\
\hline & Positive Ranks & 15 & 8.00 & 120.00 & & \\
\hline & Ties & 0 & & & & \\
\hline & Total & 15 & & & & \\
\hline \multirow{4}{*}{ Listening } & Negative Ranks & 1 & 2.50 & 2.50 & \multirow{4}{*}{3.3} & \\
\hline & Positive Ranks & 14 & 8.39 & 117.50 & & \\
\hline & Ties & 0 & & & & \\
\hline & Total & 15 & & & & \\
\hline \multirow{4}{*}{$\begin{array}{c}\text { Phonological } \\
\text { awareness }\end{array}$} & Negative Ranks & 0 & .00 & .00 & \multirow{4}{*}{3.32} & \\
\hline & Positive Ranks & 14 & 7.50 & 105.00 & & \\
\hline & Ties & 1 & & & & \\
\hline & Total & 15 & & & & \\
\hline \multirow{4}{*}{ Total } & Negative Ranks & 0 & .00 & .00 & \multirow{4}{*}{3.426} & \\
\hline & Positive Ranks & 15 & 8.00 & 120.00 & & \\
\hline & Ties & 0 & & & & \\
\hline & Total & 15 & & & & \\
\hline
\end{tabular}

Results shown in the above table illustrate that the estimated Z-value is significant at 0.05 level for each particular skill and the total score. This reflects the statistically significant difference between the mean ranks of the experimental group's pre-post-administration of the English language skills in favor of the post-administration due to using the proposed interactive e-book.

Table (6) illustrates the effect size of the interactive e-book 
concerning the difference between the experimental group's pre- and post-application of the English language skills test.

Table (6)

Value of ( $(2)$ and Levels of Effect Size

\begin{tabular}{|c|c|c|c|c|c|c|}
\hline $\begin{array}{l}\text { Independent } \\
\text { variable }\end{array}$ & $\begin{array}{r}D \\
\operatorname{dep}\end{array}$ & $\begin{array}{l}\text { mains of the } \\
\text { ndent variable }\end{array}$ & $\mathbf{Z}$ & $\begin{array}{c}\text { D. f } \\
(\mathbf{n}-1)\end{array}$ & $\begin{array}{l}\text { Value of Eta } \\
\text {-square ( } 2)\end{array}$ & $\begin{array}{c}\text { Level of } \\
\text { Effect Size }\end{array}$ \\
\hline \multirow{5}{*}{$\begin{array}{c}\text { The interactive } \\
\text { e-book }\end{array}$} & \multirow{5}{*}{ 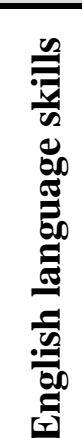 } & Word meaning & 3.43 & \multirow{5}{*}{14} & 0.98 & \multirow{5}{*}{ High } \\
\hline & & Print & 3.45 & & 0.891 & \\
\hline & & $\begin{array}{l}\text { awareness } \\
\text { Listening }\end{array}$ & 3.3 & & 0.85 & \\
\hline & & Phonological & 3.32 & & 0.86 & \\
\hline & & Total & 3.426 & & 0.885 & \\
\hline
\end{tabular}

Table (5) illustrates the effect size of the interactive e-book on the English language skills of the experimental group. Results indicate that the effect size is high in the four main skills and in the total English language performance. Accordingly, $98 \%, 89 \%, 85 \%$ and $86 \%$ of the total variance of the four main skills (identifying word meaning, print awareness, listening and phonological awareness respectively) can be attributed to the interactive e-book. Besides, $88 \%$ of the total variance of the overall English language performance can be attributed to the proposed e-book.

Results in tables (5) and (6) prove that the statistical difference between the pre- post administrations of the English language skills test is in favor of the post-application. In addition, the effect size supports the positive impact of the proposed interactive e-book on children's English language skills. Therefore, the second hypothesis of the study is proved and accepted.

\section{Discussion:}

The present study was conducted to investigate the effect of designing and using a proposed interactive e-book on developing kindergarten children's required EFL skills. The previously mentioned 
results support the positive impact of the e-book on the children's target skills. The English language performance of the experimental group was better after applying the interactive e-book when comparing it with their level before the treatment. Furthermore, children of the experimental group outperformed their counterparts of the control group in three main skills (print awareness, listening and phonological awareness) and in their overall language performance. This can be attributed to the videos, games, songs, animations, worksheets, and the other many authentic materials employed in the interactive e-book. However, no significant difference was shown between the experimental and control group children in the skill of identifying word meaning, and that was interpreted according to the similar techniques of showing meaning adopted by both the regular course and the interactive e-book course. Although both groups showed improvement in their levels but they were almost equivalent.

These findings support the earlier studies carried out on investigating the significance of e-books with kindergarten kids. For example, Korat (2008), Smeets and Bus (2014), and Takacs, Swart, and Bus (2015) fostered the impact of e-books on children's language skills including vocabulary, comprehension, reading and listening skills. Accordingly, this corresponds to the main result of the present study as the proposed interactive e-book led to improving children's skills of word meaning identification, listening, print and phonological awareness.

The interactive e-book was designed to provide children with interactive content, activities, digital communication through FaceTime App, feedback and assessment; in addition to guiding their parents 
regarding how to follow-up their children's progress to reach the optimal target language level. Such attractive features were not only motivating but also they "bring the book to life" as indicated by Smith and Schugar (2013). The children viewed the time spent in studying through the ebook as play or having fun not just a technology employed for supporting their language learning.

A concern was aroused by Smith and Schugar (2013) and Takacs, Swart, and Bus (2015) who stated that many interactive features might distract children's attention away from the actual content of the book. However, studying through the e-book accompanied with teacher's or parents' guidance and mentoring, a balance between using the interactive electronic features to support language learning and using them in a way that limits their distraction was achieved.

Besides, throughout the treatment, the proposed interactive e-book offered the experimental group children various opportunities to explore and use the English language with its different functions. Thus, children were highly engaged and motivated and this was reflected in their high level of engagement and participation recorded through the system.

\section{Conclusion}

Designing an interactive e-book appropriate for the young kindergarten children to improve their English language skill was the challenging aim of the present study. The proposed interactive e-book used different electronic elements such as videos, songs, animations, interactive games and audio files directly addressed for developing children's skills of vocabulary, listening, print and phonological awareness. The results suggested that experimental children who learned through the interactive e-book outperformed the control group who studied through the regular printed English textbook. This, in turn, 
fostered the effectiveness of the proposed interactive e-book in developing kindergarten children's English language skills. Further research on experimenting other recent electronic trends affecting kindergarten children's English language skills is highly recommended.

\section{References:}

Al-Darwish, S. (2013). Kindergarten children and language learning: Missing pillars for language acquisition. Journal of higher education, 2 (1), 44-52.

Bayhan, P., Olgun, P., \& Yelland, N. J. (2002). A study of pre-school teachers' thoughts about computer-assisted instruction. Contemporary issues in early childhood, 3(2), 298-303.

Bolstad, R. (2004). The role and potential of ICT in early childhood education. A review of New Zealand and international literature. Wellington: New Zealand Council for Educational Research.

Couse, L. J. and Chen, D. W. (2010). A tablet computer for young children? Exploring its viability for early childhood education. Journal of Research on Technology in Education, 43 (1), 75-98.

DeJong, M. T. and Bus, A. G. (2003). How well suited are electronic books to supporting literacy? Journal of early childhood literacy, 3(2), 147-164.

Davies, V. (2012). Critical review: Does electronic versus paper book experience result in differences in level of emergent literacy development in young children? Available online at: http://docplayer.net/22871207-Critical-review-does-electronicversus-paper-book-experience-result-in-differences-in-level-ofemergent-literacy-development-in-young-children.html 
Downes, T., Arthur, L., \& Beecher, B. (2001). Effective learning environments for young children using digital resources: An Australian perspective. Information Technology in Childhood Education Annual, 2001(1), 139-153. Norfolk, VA: AACE. Retrieved from: http://www.editlib.org/p/8493

Dunn, O. (2013). How young children learn English as another language. Retrieved from: https://learnenglishkids.britishcouncil.org/en/helping-yourchild/how-young-children-learn-english-anotherlanguage?page $=4$

Elgazzar, A. E. (2014) Developing eLearning Environments for Field Practitioners and Developmental Researchers: A Third Revision of An ISD Model to Meet eLearning and Distance Learning Innovations. The International Conference on Information Technology in Education (CITE 2014), Engineering Information Institute and the Scientific Research Publishing, Shenzhen, China, January 12-14, 2014.

House, R. (2012). The inappropriateness of ICT in early childhood: Arguments from philosophy, pedagogy and developmental research. In S. Suggate \& E. Reese (Eds.), Contemporary debates in childhood education and development (pp. 105-120). Oxon, England: Routledge.

Jenkins, H., et al. (2006). Confronting the challenges of participatory culture. Retrieved from http://digitallearning.macfound.org/atf/cf/\%7B7E45C7E0-A3E04B89-AC9CE807E1B0AE4E\% 7D/JENKINS_WHITE_PAPER.PDF 
Khoo, E., Merry, R., \& Nguyen, N. H., with Bennett, T., \& MacMillan, N. (2015). iPads and opportunities for teaching and learning for young children (iPads $n$ kids). Hamilton, New Zealand: Wilf Malcolm Institute of Educational Research.

Korat, O. and Shamir, A. (2007). Electronic books versus adult readers: Effects on children's emergent literacy as a function of social class. Journal of computer-assisted learning, 23(3), 248-259.

Mohammed, M. (2016).Language of instruction and the development of bi-literacy skills in children: a case study of a pre-school in the Maldives. In Murphy, V. A. and Evangelou, M. (Eds.). Early childhood education in English for speakers of other languages. London: British Council.

Moody, A. K. (2010). Using electronic books in the classroom to enhance emergent literacy skills in young children. Journal of literacy and technology, 11 (4), 22- 50.

Murphy, V. A. (2014) Second language learning in the early school years: Trends and contexts. Oxford: Oxford University Press.

Phadung, M. , Suksakulchai, S. and Kaewprapan, W. (2012). The design framework of interactive storybook support early literacy learning for ethnic minority children. Proceedings of the world congress on engineering and computer science, October 24-26, San Francisco, USA.

Smeets, D. J. H. and Bus, A. G. (2014). The interactive animated e-book as a word learning device for kindergarteners. Applied psycholinguistics, 1-22. 
Smith, C. A. and Schugar, J. T. (2013). Teaching with interactive picture e-books in grades K-6. The reading teacher, 66 (8), 615-624.

Sunhaloo, M. S., Narsoo, J. and Gopaul, A. (2009). An interactive elearning tool for kids in Mauritius. Issues in Informing Science and Information Technology. Vol. 6, 299-308.

Takacs, Z. K.; Swart, E. K. and Bus, A. G. (2015). Benefits and pitfalls of multimedia and interactive features in technology-enhanced storybooks. Review of Educational Research. 85(4), 698-739.

Wang, P. and Yang, H. (2014). The impact of e-book interactivity design on children's Chinese character acquisition. Retrieved from: https://www.tandfonline.com/doi/abs/10.1080/10494820.2014.9 $\underline{17112}$

Zhou, Y. and Ng, M. L. (2016). English as a foreign language( EFL) and English medium instruction (EMI) for three- to seven-year-old children in East Asian contexts. . In Murphy, V. A. and Evangelou, M. (Eds.). Early childhood education in English for speakers of other languages. London: British Council.

Zucker, T. A., Moody, A. K. and McKenna, M. C. (2009). The effects of electronic books on pre-kindergarten-to-grade 5 students' literacy and language outcomes: A research synthesis. Journal of educational computing research, 40 (1), 47-87.

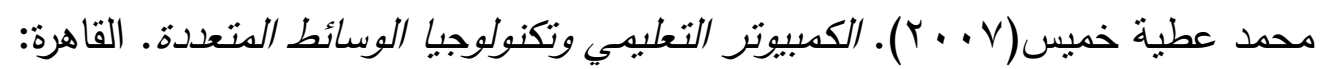

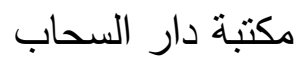

